\title{
Protein and energy requirements for maintenance of indigenous Granadina goats
}

\author{
BY C. PRIETO, J. F. AGUILERA, L. LARA AND J. FONOLLÁ \\ Estación Experimental del Zaidin (EEZ), 18008 Granada, Spain
}

(Received 12 August 1988 - Accepted 25 October 1989)

\begin{abstract}
Sixteen adult castrated male goats of the Granadina breed, with initial live weights ranging from $\mathbf{2 6 . 0}$ to $33.3 \mathrm{~kg}$ were used in two experiments to determine their protein and energy requirements for maintenance. Digestibility, nitrogen and energy balance measurements were made during the experiments. Two diets, which were based on pelleted lucerne (Medicago sativa) hay alone or on this forage and barley, were individually given at about maintenance level once daily. Gas exchange was measured using open-circuit respiration chambers. Fasting heat production was also determined. By regression analysis endogenous urinary $N$ and maintenance requirements for $N$ were estimated to be $119 \mathrm{mg} / \mathrm{kg}$ body-weight $(\mathrm{W})^{0.75}$ per $\mathrm{d}$ and $409 \mathrm{mg}$ total $\mathrm{N} / \mathrm{kg} \mathrm{W}^{0.75}$ per $\mathrm{d}$ respectively. Fasting heat production was $324 \mathrm{~kJ} / \mathrm{kg} \mathrm{W}^{0.75}$. The energy requirement for maintenance was calculated by regression of energy balance on metabolizable energy (ME) intake and a value of $443 \mathrm{~kJ} / \mathrm{kg} \mathrm{W}^{0.75}$ per d was found. The overall efficiency of utilization of ME for maintenance was 0.73 .
\end{abstract}

Energy requirement: Proteiß requirement: Goats

There is little information in the literature concerning nutritional requirements of goats, probably because of the minor economical importance of the goat in developed countries. In fact, most recommendations have been derived from other ruminant species, e.g. cattle and sheep. However, these extrapolations may be misleading as it is well-recognized that the goat has developed unusual physiological features in comparison with other ruminants, such as a higher capacity to degrade cell wall components of low-quality forages and a better ability to use nitrogen and water under stress conditions.

Most information on energy and protein requirements of goats has been obtained by feeding trials (Devendra, 1967; Singh \& Sengar, 1970; Akinsoyinu, 1974; Rajpoot, 1979; Morand-Fehr, 1981; Aguilera et al. 1984). Estimates of energy needs based on calorimetry experiments are very limited. In non-lactating goats, fasting metabolism values were reported by Brody (1945), Fujihara et al. (1973) and Roy-Smith (1980), but no direct estimations of energy requirements for maintenance have been found in the literature. Values for nitrogen requirements, based on $\mathrm{N}$ balance studies in non-lactating goats, are also scarce (Itoh et al. 1978; Reynolds, 1981; Guerrero, 1982). Consequently, further research is needed on the nutrient requirements of goats. Some findings on the energy and protein needs of lactating goats are published in the following paper (Aguilera et al. 1990). The present work was undertaken with the specific aim of providing information on the protein and energy requirements for maintenance in adult castrated male goats of the Granadina breed, a native species well-adapted to arid lands in Southern Spain.

\section{MATERIAL AND METHODS}

Animals and diets

Sixteen adult castrated male goats, 23 years of age, of initial live weight ranging from $26 \cdot 0$ to $33.3 \mathrm{~kg}$, were used in two consecutive experiments. In each experiment, eight goats 
Table 1. Composition of the experimental diets $(\mathrm{g} / \mathrm{kg})$

\begin{tabular}{|c|c|c|c|c|}
\hline \multirow{2}{*}{$\begin{array}{l}\text { Diet... } \\
\text { Expt no.... }\end{array}$} & \multicolumn{2}{|c|}{ Mixed diet } & \multicolumn{2}{|c|}{$\begin{array}{c}\text { Lucerne (Medicago sativa) } \\
\text { hay-based diet }\end{array}$} \\
\hline & 1 & 2 & 1 & 2 \\
\hline \multicolumn{5}{|l|}{ Ingredients } \\
\hline Pelleted lucerne hay & 570 & 620 & 985 & 985 \\
\hline Barley & 415 & 365 & - & - \\
\hline Mineral mixture* & 15 & 15 & 15 & 15 \\
\hline \multicolumn{5}{|l|}{ Analysis (g/kg dry matter (DM)) } \\
\hline $\mathrm{DM}(\mathrm{g})$ & 887 & 902 & 883 & 906 \\
\hline Organic matter & 930 & 905 & 895 & 863 \\
\hline Crude protein (nitrogen $\times 6.25$ ) & 137 & 171 & 162 & 212 \\
\hline Gross energy $(\mathrm{MJ} / \mathrm{kg} \mathrm{DM})$ & 18.5 & 17.9 & $18 \cdot 7$ & 17.5 \\
\hline
\end{tabular}

* The mineral mixture contained $(\mathrm{g} / \mathrm{kg}): \mathrm{CaPO}_{4} \cdot 2 \mathrm{H}_{2} \mathrm{O} 600, \mathrm{NaCl} 250, \mathrm{MgO} 150$.

were distributed on a body-weight (W) basis into two groups of four animals each. Following a cross-over design, each group consumed a diet based on pelleted lucerne (Medicago sativa) hay alone or with the addition of barley (mixed diet). A balance trial was conducted on each diet. The digestibility of barley was calculated by difference. The experimental diets (Table 1) were given at a maintenance level, which was taken as $0.548 \mathrm{MJ}$ metabolizable energy (ME) $/ \mathrm{kg} \mathrm{W}^{0.75}$, a value for lactating goats which had been obtained in our laboratory by feeding-trials (Aguilera et al. 1984). A previous estimation of the ME content of the diets was made from the reported energy value of the ingredients (Nehring et al. 1972).

\section{Experimental procedure}

The male goats, previously dosed with Tetramisol (Sobrino, S.A.) against internal parasites, were kept in individual metabolism cages placed in an environmentally controlled room at $22-24^{\circ}$. They were fed once daily at $09-00$ hours. Each digestibility trial consisted of a $15 \mathrm{~d}$ preliminary period followed by a $10 \mathrm{~d}$ balance period in which faeces and urine were collected daily and stored at $-25^{\circ}$. At the end of the collection period, representative samples were taken for analysis. No preservative for urine was used. The goats were weighed at the beginning and end of the balance period. Food intakes were recorded daily and any refusals taken into account. Throughout each balance period, on days 17, 19, 21 or 23 , after a $24 \mathrm{~h}$ adaptation period, oxygen consumption and carbon dioxide and methane production of each goat were measured for $24 \mathrm{~h}$ in open-circuit respiration chambers described elsewhere (Aguilera \& Prieto, 1986), and heat production (HP) was calculated according to the equation of Brouwer (1965). Measurements of HP were staggered as only two chambers were available. At the end of each balance experiment, the goats were fasted for $72 \mathrm{~h}$ and then, after a concomitant $48 \mathrm{~h}$ adaptation period to the respiration procedures, HP was also measured for $24 \mathrm{~h}$. All animals had previously been trained to confinement and to the routine procedures of the chamber operations. As difficulties had been experienced in collecting urine in the confined space of the respiration chambers, no collection of urine was made during the HP measurements.

\section{Chemical analysis}

Total $\mathrm{N}$ in feeds, urine and wet faeces was determined by a Kjeldahl procedure using mineralization (Block Digestor Selecta S-509) and distillation units (Büchi Laboratoriums 
Technik AG, Flawil, Switzerland; working capacity from 100 to $500 \mathrm{ml}$ ) and titration units from Metrom AG, Herisau, Switzerland (Dosimat 655, Digital pH-Meter 632 and Impulsomat 614). Crude protein was calculated from the $\mathrm{N}$ content using the factor $6 \cdot 25$. The gross energy of feeds and freeze-dried faeces and urine was measured in an adiabatic bomb calorimeter (Gallenkamp \& Co. Ltd, London). Samples were freeze-dried in a polyethylene sheet of known energy value and their gross energy values were obtained by difference. Dry matter and organic matter determinations were carried out by standard procedures (Association of Official Analytical Chemists, 1975).

\section{Statistical treatment}

The main effects of the experiments were analysed using a split-plot ANOVA (Snedecor \& Cochran, 1980), which was arranged as follows: experiments (1 df); live weight blocks within experiments $(2 \mathrm{df})$; between goats $(12 \mathrm{df})$, in the main plot analysis, and periods $(1 \mathrm{df})$; diets $(1 \mathrm{df})$; experiments $\times$ diets $(1 \mathrm{df})$; experiments $\times$ periods $(1 \mathrm{df})$, in the sub-plot analysis. When the analysis was significant, pairwise comparisons were made using the suitable standard error of difference (SED). Regression analysis was used throughout, with values being pooled whenever appropriate.

\section{RESULTS}

\section{Digestibility and $N$ balance}

Table 2 shows the apparent digestibility and the energy content of the experimental diets, the digestibility of barley being calculated by difference. Values from the two consecutive experiments performed with the goats (i.e. Expts 1 and 2) are presented separately. Significant differences in apparent digestibility and metabolizability of energy between diets but not between experiments were found.

The $\mathrm{N}$ balance results appear in Table 3. The mean $\mathrm{N}$ retention during Expt 2 was higher than in Expt 1 as the result of a greater dietary $\mathrm{N}$ content and a slightly better utilization of the $\mathrm{N}$ absorbed. Also, the higher $\mathrm{N}$ content of the diets based on lucerne hay can account for the differences in $\mathrm{N}$ retention observed between diets. When $\mathrm{N}$ retention (NR) was regressed $v . \mathrm{N}$ intake $(\mathrm{NI})\left(\mathrm{g} / \mathrm{kg} \mathrm{W}^{0.75}\right.$ per $\left.\mathrm{d}\right)$, two separate linear relationships, one for the lucerne diet and one for the mixed diet, were calculated. As these separate regressions did not differ significantly one from the other, a composite regression was established on pooled values:

$$
\mathrm{NR}=0.264(\mathrm{SE} 0 \cdot 022) \mathrm{NI}-0 \cdot 108(\mathrm{SE} 0 \cdot 009), r 0 \cdot 907, \mathrm{RSD} 0 \cdot 050,
$$

where RSD is the residual standard deviation, which suggested that at $\mathrm{N}$ equilibrium a daily intake of $409 \mathrm{mg} \mathrm{N} / \mathrm{kg} \mathrm{W}^{0.75}$ per $\mathrm{d}$ is required. In addition, the value of $\mathrm{N}$ balance at zero NI from this equation gives an estimation of the total endogenous nitrogen losses (TEN; $108 \mathrm{mg} \mathrm{N} / \mathrm{kg} \mathrm{W}^{0.75}$ per d).

Endogenous urinary $\mathrm{N}$ losses (EUN) were calculated from the intercept of the regression of urinary $\mathrm{N}(\mathrm{UN}) v$. NI $\left(\mathrm{g} / \mathrm{kg} \mathrm{W}^{0.75}\right.$ per $\left.\mathrm{d}\right)$. The composite regression was:

$$
\mathrm{UN}=0.336(\mathrm{SE} 0 \cdot 028) \mathrm{NI}+0 \cdot 119(\mathrm{SE} 0 \cdot 011), r 0 \cdot 911, \mathrm{RSD} 0 \cdot 062 \text {, }
$$

which indicates a value for EUN of $119 \mathrm{mg} \mathrm{N} / \mathrm{kg} \mathrm{W}^{0.75}$ per $\mathrm{d}$.

\section{Energy balance}

Table 4 shows the energy balance of goats fasted or fed at about maintenance level. The mean energy balance was close to maintenance and slightly negative for the mixed diet and the lucerne diet respectively. Energy intake during Expt 2 was higher than in Expt 1 and this fact is attributed to an underestimation made when predicting the ME content of the 

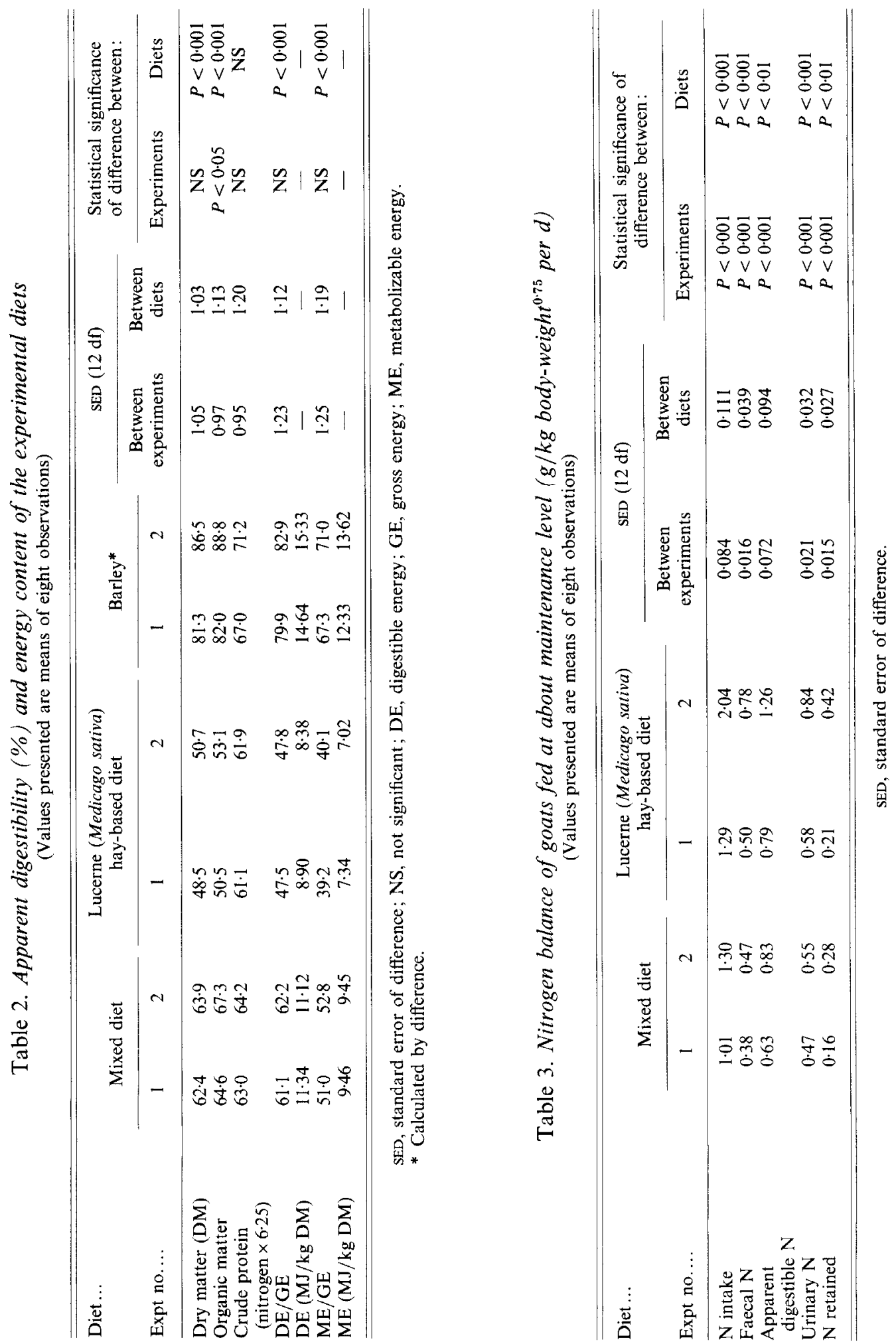
MAINTENANCE REQUIREMENTS IN GOATS

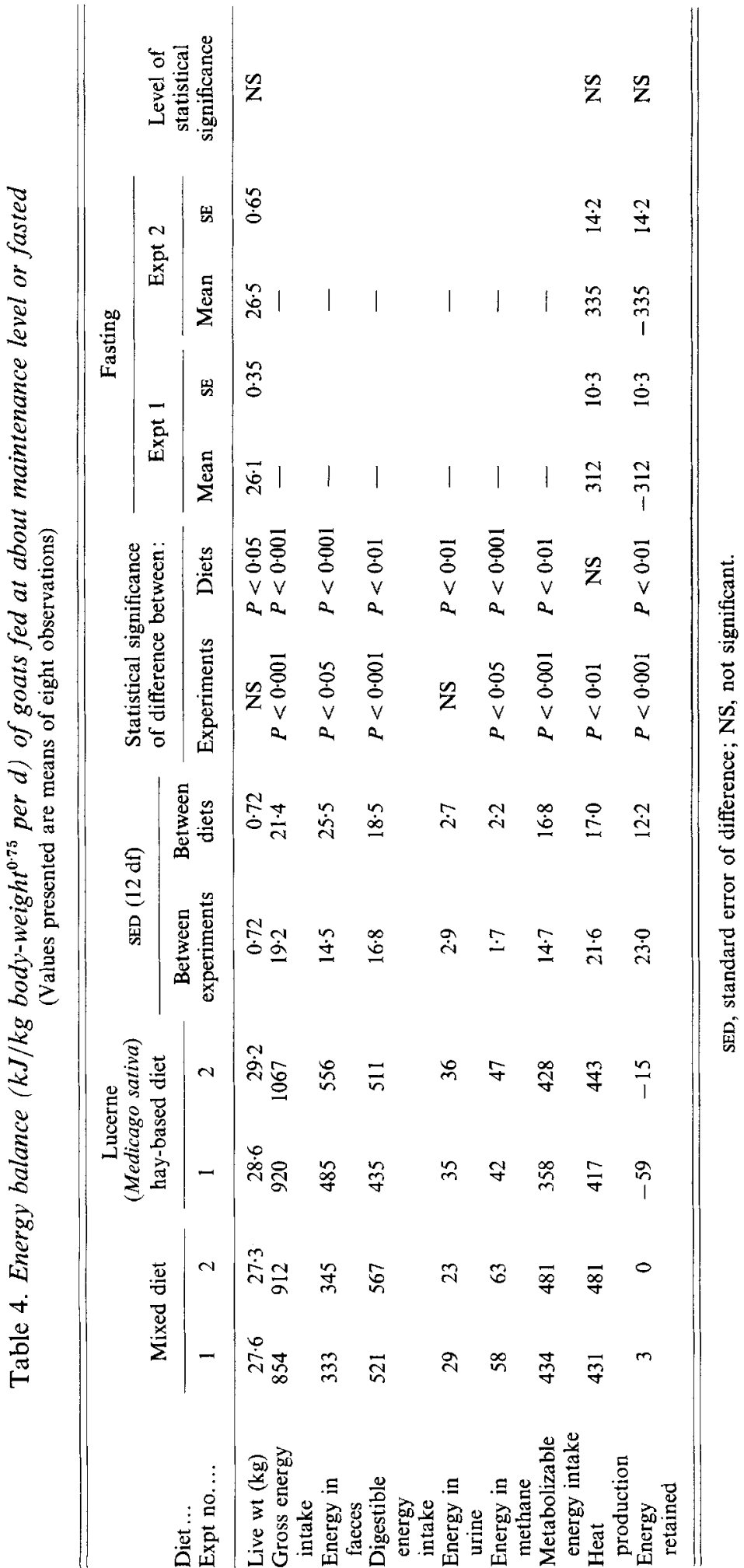


Table 5. Estimates of energy requirements for maintenance $\left(M E_{m}\right)$ of adult goats fed at two fixed levels of intake

(All energy values are expressed as $\mathrm{kJ} / \mathrm{kg}$ body-weight ${ }^{0.75}$ per $\mathrm{d}$ )

\begin{tabular}{|c|c|c|c|c|c|}
\hline Diet & Linear regression equations & RSD & $r$ & $\mathrm{ME}_{\mathrm{m}}^{*}$ & SE \\
\hline Lucerne hay & $\mathrm{RE}=-326(\mathrm{SE} 8)+0.730(\mathrm{SE} 0.05) \mathrm{MEI}$ & $35 \cdot 69$ & 0.966 & 447 & $52 \cdot 9$ \\
\hline Mixed diet & $\mathrm{RE}=-325(\mathrm{SE} 9)+0.739(\mathrm{SE} 0.04) \mathrm{MEI}$ & $38 \cdot 95$ & 0.969 & 440 & $56 \cdot 3$ \\
\hline Overall & $\mathrm{RE}=-324(\mathrm{SE} 8)+0.732(\mathrm{SE} 0.04) \mathrm{MEI}$ & $39 \cdot 29$ & 0.969 & 443 & $56 \cdot 1$ \\
\hline
\end{tabular}

RE, total energy retention; MEI, metabolizable energy intake; RSD, residual standard deviation.

* Value for MEI when RE $=0$.

lucerne hay. Significant differences in live weight between diets were observed, which can be accounted for by differences in gut fill. In order to convert fasted weight into weight at maintenance, empty-body-weight (EBW, $\mathrm{kg}$ ) was related to live weight $(\mathrm{LW}, \mathrm{kg})$ by the equation: $\mathrm{EBW}=\mathrm{LW} / 1.08$ (Blaxter et al. 1966). In the experiments with animals fed at about maintenance level, the overall apparent body energy balance was negative. In a small number of cases slightly positive energy retentions were found and then a correction for the intake of ME (MEI) above maintenance was made, as the efficiency of use of ME for production $\left(k_{f}\right)$ is much lower than that for maintenance $\left(k_{m}\right)$. To this purpose, $k_{f}$ was estimated according to the equation: $k_{f}=0.78 q_{m}+0.006$ (Blaxter, 1974), where $q_{m}$ is the metabolizability of the diet.

Mean values of fasting HP were 312 and $355 \mathrm{~kJ} / \mathrm{kg} \mathrm{W}^{0.75}$ per $\mathrm{d}$ in Expts 1 and 2 respectively (Table 4). EUN was assumed to be $119 \mathrm{mg} / \mathrm{kg} \mathrm{W}^{0.75}$ per d (equation 2). No statistical differences with respect to fasting HP between experiments were found.

Measurements of energy balance of goats at the two feeding levels considered (about maintenance and fasting) have been used to predict the energy intake at zero energy retention, using a linear regression of energy retention (RE) v. MEI :

$$
\mathrm{RE}\left(\mathrm{kJ} / \mathrm{kg} \mathrm{W}^{0.75} \text { per } \mathrm{d}\right)=-a+b \times \mathrm{MEI}\left(\mathrm{kJ} / \mathrm{kg} \mathrm{W}^{0.75} \text { per } \mathrm{d}\right),
$$

where $\mathrm{RE}=\mathrm{MEI}-$ total $\mathrm{HP}$ in $\mathrm{kJ} / \mathrm{kg} \mathrm{W}^{0 \cdot 75}$ per $\mathrm{d}, b$ is $k_{m}$, and $a$ is fasting HP. The equation predicts $\mathrm{ME}$ for maintenance $\left(\mathrm{ME}_{\mathrm{m}}\right)$ when $\mathrm{RE}=0$ and also provides an estimate of the efficiency of utilization of ME for maintenance $\left(k_{m}\right)$. Table 5 summarizes the values obtained for $\mathrm{ME}_{\mathrm{m}}$ and $k_{m}$ for the lucerne diet and for the mixed diet (447 and $440 \mathrm{~kJ} / \mathrm{kg} \mathrm{W}^{0.75}$ per $\mathrm{d}$ and 0.73 and 0.74 respectively). As no statistical differences attributable to the diet were found, a composite regression was calculated giving for $\mathrm{ME}_{\mathrm{m}}$ a value of $443 \mathrm{~kJ} / \mathrm{kg} \mathrm{W}^{0.75}$ per $\mathrm{d}$ and for $k_{m}$ a value of 0.73 .

\section{DISCUSSION}

\section{Digestibility and $N$ balance}

The digestibility and metabolizability coefficients for energy and the energy values of lucerne hay and barley were within the range of expected values.

Values for the intercepts from equations 1 and 2 were not statistically different. Thus estimates of both the TEN (equation 1) and EUN (equation 2) suggest that at the MEI close to maintenance, EUN is the main endogenous $\mathrm{N}$ loss, in agreement with studies by Ørskov \& MacLeod (1982).

EUN can be estimated by direct measurement (Rajpoot, 1979; Mudgal \& Singh, 1981) or by regression (equation 2), the former approach giving values somewhat lower than the latter. Reported values for EUN in non-lactating goats range from $40 \mathrm{mg} \mathrm{N} / \mathrm{kg} \mathrm{W}^{0.75}$ per 
$\mathrm{d}$ in dry dwarf goats (Akinsoyinu et al. 1976) to $240 \mathrm{mg} \mathrm{N} / \mathrm{kg} \mathrm{W}^{0.75}$ per d in castrated male goats (Itoh et al. 1978). The value of $119 \mathrm{mg} \mathrm{N} / \mathrm{kg} \mathrm{W}^{0.75}$ per d obtained in the present paper from equation 2 is close to those obtained by Rajpoot et al. (1980), Reynolds (1981) and Guerrero (1982) in castrated male goats $\left(115,120\right.$ and $123 \mathrm{mg} \mathrm{N} / \mathrm{kg} \mathrm{W}^{\mathbf{0 . 7 5}}$ per d respectively) and somewhat lower than those of Majumdar (1960) and Devendra (1982) in dry goats (126 and $133 \mathrm{mg} \mathrm{N} / \mathrm{kg} \mathrm{W}^{0.75}$ per d respectively). Our value for EUN is higher than EUN losses of $97 \mathrm{mg} \mathrm{N} / \mathrm{kg} \mathrm{W}^{0.75}$ per d, which can be calculated for a sheep of $30 \mathrm{~kg}$ live weight (LW) from the following equation (Agricultural Research Council, 1980): EUN $=0 \cdot 02348$ $\mathrm{LW}+0.54$.

The maintenance requirement for $\mathrm{N}$ estimated in the present paper from equation 1 is lower than the values of $485 \mathrm{mg}$ dietary $\mathrm{N} / \mathrm{kg} \mathrm{W}^{0.75}$ per d (Itoh et al. 1978) and $688 \mathrm{mg}$ dietary $\mathrm{N} / \mathrm{kg} \mathrm{W}^{0 \cdot 75}$ per d (Reynolds, 1981). Akinsoyinu et al. (1976) obtained a value as low as $140 \mathrm{mg}$ dietary $\mathrm{N} / \mathrm{kg} \mathrm{W}^{0.75}$ per $\mathrm{d}$ in West African dwarf goats.

As discussed later, in our experiments $\mathrm{ME}_{\mathrm{m}}$ was estimated as $443 \mathrm{~kJ} / \mathrm{kg} \mathrm{W}^{0.75}$ per $\mathrm{d}$. According to the Agricultural Research Council (1980), this amount of ME would yield $555 \mathrm{mg}$ rumen microbial $\mathrm{N}$, supplying $233 \mathrm{mg} / \mathrm{kg} \mathrm{W}^{0.75}$ of net amino acid- $\mathrm{N}$ for tissue synthesis, a value which exceeds the TEN obtained in our experiments. Consequently, the goat's requirement for amino acid- $\mathrm{N}$ would be met by rumen microbial protein synthesis, which is in agreement with statements by Roy et al. (1977) for other ruminants fed at an energy level close to maintenance.

\section{Respiration measurements}

There are very few direct estimations of fasting HP for adult non-lactating goats in the literature. Our overall value of $324 \mathrm{~kJ} / \mathrm{kg} \mathrm{W}^{0.75}$ per $\mathrm{d}$ is close to that of Roy-Smith (1980) $\left(331 \mathrm{~kJ} / \mathrm{kg} \mathrm{W}^{0.75}\right.$ per d) but lower than those reported by Brody (1945) and Fujihara et al. (1973) (386 and $357 \mathrm{~kJ} / \mathrm{kg} \mathrm{W}^{0.75}$ per d respectively) and higher than the values for fasting metabolism in sheep published by the Agricultural Research Council (1980). In addition, in our laboratory (Aguilera et al. 1986) a value of $272 \mathrm{~kJ} / \mathrm{kg} \mathrm{W}^{0.75}$ per d was estimated for adult wethers following the same experimental approach as that described in the present paper, a value which was also found by Roy-Smith (1980) in his comparative study between goats and sheep.

In addition, following the equation proposed by the Agricultural Research Council (1980) for mixed diets: $k_{m}=0.207 q_{m}+0.62$, values of $k_{m}$ ranging from 0.73 to 0.75 would be derived from our experiments, which compare very well with those reported in the present paper (0.73) (Table 5).

As shown in Table 5, $\mathrm{ME}_{\mathrm{m}}$ values were 447 and $440 \mathrm{~kJ} / \mathrm{kg} \mathrm{W}^{0.75}$ per $\mathrm{d}$ for goats fed on the lucerne hay and the mixed diet respectively. As no statistical differences attributable to the diet were found, a composite regression was calculated giving for $\mathrm{ME}_{\mathrm{m}}$ a value of $443 \mathrm{~kJ} / \mathrm{kg} \mathrm{W}^{0.75}$ per $\mathrm{d}$.

To our knowledge, all reported values on $\mathrm{ME}_{\mathrm{m}}$ for goats have been obtained by feeding trials. Our value of $443 \mathrm{~kJ} / \mathrm{kg} \mathrm{W}^{0.75}$ per $\mathrm{d}$, which is based on calorimetry results, is slightly higher than that estimated by the National Research Council (1981) for goats ( $424 \mathrm{~kJ} \mathrm{ME} / \mathrm{kg} \mathrm{W}^{0 \cdot 75}$ per $\mathrm{d}$ ), a value which is derived from pooled means of experimental values. The $M E_{m}$ obtained in the present work is in the range of published values on fattening cattle and dry cows (from 418 to $469 \mathrm{~kJ} / \mathrm{kg} \mathrm{W}^{0 \cdot 75}$ per d), which have been summarized by the Agricultural Research Council (1980). From our results, a maintenance requirement of $5.7 \mathrm{MJ} \mathrm{ME} / \mathrm{d}$ can be derived for goats of $30 \mathrm{~kg} \mathrm{LW}$. This value is higher than that reported by the Agricultural Research Council (1980) for sheep of similar weight (5.0 MJ ME/d) a finding which is in agreement with the higher fasting metabolism observed in goats. 
The authors wish to thank Mrs E. Colmenero and Miss F. Gil for skilful technical assistance and Mr A. Velázquez for the care of animals. This work was supported by the Junta de Andalucía and the Spanish Research Council (Project no. 316).

\section{REFERENCES}

Agricultural Research Council (1980). The Nutrient Requirements of Ruminant Livestock. Slough: Commonwealth Agricultural Bureaux.

Aguilera, J. F., Guerrero, J. E., Molina, E. \& Boza, J. (1984). Eficiencia de utilización energética para la lactación en ganado caprino. $9^{\text {as }}$ Jornadas Cientificas de la Sociedad Española de Ovinotecnia y Caprinotecnia, pp. 305-310. Granada y Málaga: Excmas. Diputaciones Provinciales.

Aguilera, J.F., Molina, E., Prieto, C. \& Boza, J. (1986). Estimación de las necesidades energéticas de mantenimiento en ganado ovino de raza Segureña. Archivos de Zootecnia 35, 89-96.

Aguilera, J. F. \& Prieto, C. (1986). Description and function of an open-circuit respiration plant for pigs and small ruminants and the techniques used to measure energy metabolism. Archives of Animal Nutrition Berlin 36, $1009-1018$.

Aguilera, J. F., Prieto, C. \& Fonollá, J. (1990). Protein and energy metabolism of lactating Granadina goats. British Journal of Nutrition 63, 165-175.

Akinsoyinu, A. O. (1974). Studies of protein and energy utilization by the West African dwarf goats. PhD Thesis, University of Ibadan, Nigeria.

Akinsoyinu, A. O., Mba, A. U. \& Olubayo, F. O. (1976). Crude protein requirement of West African Dwarf goats for maintenance and gain. Journal of the Association for the Advancement of Agricultural Sciences in Africa 3, $75-80$.

Association of Official Analytical Chemists (1975). Official Methods of Analysis, 12th ed. Washington, DC: AOAC.

Blaxter, K. L. (1974). Adjustments of the metabolism of the sheep to confinement. In Proceedings of 6th European Association for Animal Production Symposium on Energy Metabolism, Publication no. 14, pp. 115-118 [K. H. Menke, H. J. Lantzsch and R. J. Reichl, editors]. Hohenheim: Universitäts Dokumentationsstelle.

Blaxter, K. L., Wainman, F. W. \& Davidson, J. L. (1966). The voluntary intake of food by sheep and cattle related to their energy requirements for maintenance. Animal Production 8, 75-83.

Brody, S. (1945). Bioenergetics and Growth. New York: Hafner Press.

Brouwer, E. (1965). Report of Sub-committee on Constants and Factors. In Proceedings of 3rd European Association for Animal Production Symposium on Energy Metabolism, Publication no. 11, pp. 441-443 [K. L. Blaxter, editor]. London: Academic Press.

Devendra, C. (1967). Studies in the nutrition of the indigenous goat of Malaysia. I. The maintenance requirements of pen-fed goats. Malaysian Agricultural Journal 46, 80-97.

Devendra, C. (1982). The protein requirements for maintenance of indigenous Kambing Katjang goats in Malaysia. Nutrition Abstracts and Reviews 52, 281.

Fujihara, T., Tasaki, I. \& Furuhashi, T. (1973). Energetic utilization of starch introduced into the abomasum of goats. In Proceedings of the 6th European Association for Animal Production Symposium on Energy Metabolism, Publication no, 14, pp. 67-70 [K. H. Menke, J. H. Lantzsch and J. R. Reichl, editors]. Hohenheim: Universitäts Dokumentationsstelle.

Guerrero, J. E. (1982). Estudio de la alimentación del ganado caprino. Utilización de subproductos y ensayos de lactación en cabras de raza Granadina. PhD Thesis, University of Córdoba.

Itoh, M., Haryu, T., Tano, R. \& lwasaki, K. (1978). Maintenance requirement of energy and protein for castrated Japanese native goats. Bulletin of National Institute of Animal Industry no. 33, pp. 41-50. Nishigoshi, Kumamoto: Kyushu National Agricultural Experimental Station.

Majumdar, B. N. (1960). Studies on goat nutrition. I. Minimum protein requirements for maintenance, endogenous urinary nitrogen and metabolic faecal nitrogen excretion studies. Journal of Agricultural Science, Cambridge 54, 329-334.

Morand-Fehr, P. (1981). Nutrition and feeding of goats: application to temperate climatic conditions. In Goat Production, pp. 193-232 [C. Gall, editor]. London: Academic Press.

Mudgal, V. D. \& Singh, N. (1981). Nitrogen excretion and protein requirements by goats receiving low N diets. In Nutrition and Systems of Goat Feeding, vol. 1, pp. 142-15] [P. Morand-Fehr, A. Bourbouze and M. de Simiane, editors]. Tours: [TOVIC-INRA.

National Research Council (i981). Nutrient Requirements of Domestic Animals Publication no. 15. Washington, DC: National Academy Press.

Nehring, K., Beyer. M. \& Hofimann, B. (i972). Futtermittel Tabellenwerk. Berlin: Veb Deutscher, Landwirtschaftsverlag.

Ørskov, E. R. \& McLeod. N. A. (1982). The determination of the minima! nitrogen excretion in stecrs and dairy cows and its physiological and practica! implication. British Journal of Nutrition 47, 625-636. 
Rajpoot, R. L. (1979). Energy and protein in goat nutrition. PhD Thesis. Raja Balwant Singh College, Bichpuri (Agra), India.

Rajpoot, R. L., Sengar, O. P. S. \& Singh, S. N. (1980). Goats: protein requirement for maintenance. International Goat and Sheep Research 1, 182-189.

Reynolds, L. (1981). Nitrogen metabolism in indigenous Malawi goats. Journal of Agricultural Science, Cambridge 96, 347-351.

Roy, J. H. B., Balch, C. C., Miller, E. R., Ørskov, E. R. \& Smith, R. H. (1977). Calculation of the N-requirement for ruminants from nitrogen metabolism studies. In Proceedings of the 2nd European Association for Animal Production Symposium on Protein Nutrition and Metabolism, Publication, no. 22, pp. 126-129. Wageningen: Pudoc.

Roy-Smith, F. (1980). The fasting metabolism and relative energy intake of goats compared with sheep. Animal Production 30, 491.

Singh, S. N. \& Sengar, O. P. S. (1970). Investigation on milk and meat potentialities of Indian goats, 1965-70. Final Technical Report Project no. A7-AH18. Bichpuri (Agra), India: Raja Balwant Singh College.

Snedecor, G. W. \& Cochran, W. G. (1980). Statistical Methods, 7th ed. lowa State University Press. 